\title{
DEVELOPMENT OF EDUCATION FOR SUSTAINABLE DEVELOPMENT (ESD) BASED CHEMSDRO MOBILE LEARNING FOR INDONESIAN JUNIOR HIGH SCHOOL: RATE OF REACTION
}

\author{
Anita Fibonacci ${ }^{1 *}$, Zidni Azizati $^{1}$ and Tomi Wahyudi ${ }^{1}$ \\ ${ }^{1}$ Department of Chemistry Education, Faculty of Science and Technology, Universitas Islam \\ Negeri Walisongo, Jl. Prof. Dr. Hamka, Semarang, 50183, Indonesia \\ *E-mail: anitafibonacci@walisongo.ac.id
}

Received: 22 October 2019; Accepted: 14 March 2020; Published: 30 June 2020

\begin{abstract}
ICT learning media mostly emphasize students content and motivation. The emphasis on protecting the environment as a form of development of sustainable living awareness is often considered not significant. Accordingly, many youth students begin to lose development of sustainable living awareness. This study aimed to produce and evaluate a learning media based on games in Android mobile learning-Chemsdro (Chemistry in Android) oriented to Education for Sustainable Development (ESD) on the topic rate of reaction: Characteristic of Chemsdro Learning Media was the topic of rate of reaction created in the form of games that embedded in android mobile phones with game characters who have a mission to protect the environment. This learning tool was designed to give motivation for students to care about the environment. This research was Research and Development model, it was adopted the steps from Thiagarajaan including define, design, develop, and dissemination steps. The subjects of this study were students grade XI of SMA 1 Kendal. The product validation showed that the Chemsdro learning media was a very appropriate category to use with the Aiken $\mathrm{V}$ coefficient of 0.9 . Student assessment of Chemsdro learning media also showed a good category.
\end{abstract}

Keywords: games, android, education for sustainable development (ESD), rate of reaction

DOI: https://doi.org/10.15575/jtk.v5i1.5908

\section{INTRODUCTION}

The development of science and technology at this time cannot be avoided any more influence in the world of education so it demands the education world to always adjust the development of technology to improve the quality of education (Rusdi \& Yunus, 2014). One technology that can support the needs of students is gadgets, tablets, and smartphones (Muyaroah \& Fajartia, 2017). One way to implement technology in learning is through learning media (Yektyastuti \& Ikhsan, 2016). Heinich et al. (1999) stated that learning media 
became a bridge between teachers and students; especially learning media for Information and Communication Technology (ICT), students were not limited by classrooms which meant students had high flexibility in learning.

ICT- based learning media emerged as a new instrument with a variety of developments (Abanikannda, 2016). The development of a mobile learning-based system provides opportunities for students to access information that is needed in their academic life quickly and easily (El-Sofany et al., 2014). The use of instructional media based on ICT has the power to help improve academic performance of students in the cognitive domain and students' learning motivation (Yektyastuti \& Ikhsan, 2016).

Professional development in this century, several challenges can be faced by technologies that have evolved (Díaz et al., 2019). Implementation of learning using a smartphone has a positive impact on the dimensions of affective, cognitive, sociocultural and metacognitive. Smartphones have the power to transform abstract learning experiences into real visualization (Nugroho \& Purwandari, 2016). Using a smartphone in the learning process can invite new interests, and enhance student's motivation (Rohmah, 2014). Interactive media can be a supplement and complement in learning that represents learning resources (Jauhari, 2009).

Chemistry learning has an important role as one of the subjects for the implementation of learning based on sustainable development (education for sustainable development). Various chemical concepts have close links with the environment to stimulate the creativity and innovation of students to be able to use chemical concepts to solve environmental problems (Fibonacci, 2012).

An increasingly worrisome environment due to environmental destruction, especially forests due to illegal logging, peat land fires, expansion of oil palm plantations, developments, etc. cause (Arslan et al., 2011). This is where the concept of Educational for Sustainable Development is very important to apply so that development goes well without putting aside the environment (Laurie et al., 2016). The use of smartphones can also reduce the amount of paper, which is an effort to support environmental sustainability in line with the goals of Educational for Sustainable Development (ESD). The reaction rate is one topic that can be used to emphasize the importance of protecting the environment, through adventure games.

Nowadays, the lack of character is stated as one of the problems of education that began to emerge in millennial generation. ESD can be one solution to overcome this problem (Engjellushe, 2013). ESD has been carried out in several countries and recommended by the United Nations Educational, Scientific, and Cultural Organization (UNESCO) to increase student's awareness of the environment (Segara, 2015; Ulum et al., 2019) In fact, the concept of ESD issued by the United Nations can be one of the solutions to develop an environmentally sound economy and can be included in the chemistry learning process to be able to foster and equip students' attitudes and knowledge, especially the attitude of environmental awareness (Perkasa et al., 2017).

ESD can be applied in learning, an example is in learning with the topic of Reaction Rate. Reaction rate is one part of basic chemistry that is not yet fully discussed at the secondary school level (Ahiakwo \& Isiguzo, 2015; Vos \& 
Development of Education for Sustainable

Development (ESD) based Chemsdro Mobile Learning for Indonesian Junior High School: Rate Of Reaction

Verdonk, 1985) this is presumably because the learning process only emphasizes numbers and calculations, without relating to the characters needed in life. The reaction rate as a highly structured material is a central part of the chemistry curriculum, therefore, understanding the concepts relating to the reaction rate has an important role in learning chemistry (Cachapuz \& Maskill, 1987). One way to implement ESD in the reaction rate material is by linking the use of catalysts in the production of biodiesel and catalytic converters in motor vehicles (Sidabutar et al., 2013), so students do not just focus on calculating numbers without knowing the benefits in the real world.

Most ICT learning media only emphasize student content and motivation. The emphasis of character such as protecting the environment as a form of awareness of the development of sustainable living is often considered not significant. As a result, many teenage students begin to lose awareness of the development of sustainable life. This is the reason Chemsdro's media was developed with the orientation to emphasize the characters such as an environmental awareness. The reduction of combustion results from motor vehicles is the mission in this Chemsdro game to motivate students to be aware that the use of motorized vehicles results in a considerable has impact to he environment.

\section{RESEARCH METHOD}

This research method was Research and Development Research, with the 4D development model (Define, Design, Develop, and Disseminate) (Thiagarajaan et al., 1974). It generally consists of four stages, namely Define, Design, Develop and Disseminate.
The Define stage was carried out through 5 stages as listed in Figure 1, namely (a) frontend analysis; (b) learner analysis; (c) task analysis; (d) concept analysis; (e) formulation of learning objectives (specifying instructional objectives). All information obtained from this stage was used to formulate the basic problems that exist in the school and to get the prototype characteristics of the learning media to be developed.

The design phase, the activities carried out were (a) format selection; (b) media selection; and (c) the initial design of teaching materials so that an initial draft of the product is developed.

The develop phase was aimed to produce a final form of media that is suitable for use. The activities carried out were (a) expert appraisal (expert judgment), in this activity an evaluation was carried out by an expert on the product being developed. Expert judgment was used to determine the validity of the product and to fond input and suggestions for improvement of the product being developed; (b) developmental testing, was a product design trial run on the actual target subject. The developmental testing phase in this study only reached the initial testing part, which was a limited trial on the research subject.

The subjects of this study were students of class XI SMA Negeri 1 Kendal, Indonesia. Data analysis techniques in this study used expert validation and student questionnaire responses to the Chemsdro media. The Chemsdro media validity instrument was based on the results of the validation questionnaire assessment using a rating scale of 5 . The validation results are calculated with the validity of Aiken's $V$ as shown in equation 1 (Azwar, 2012). 


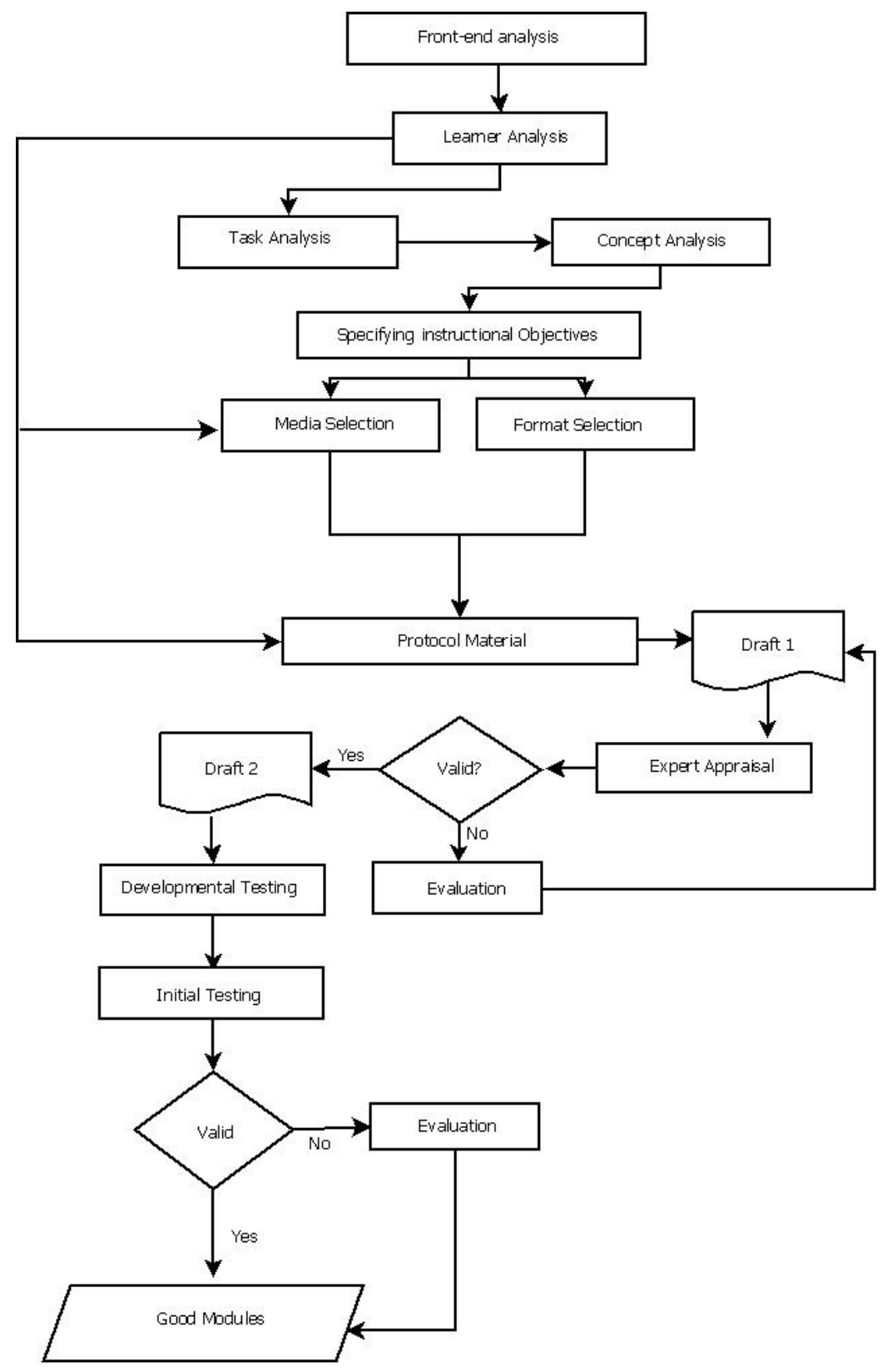

Figure 1. R\&D Stages

$$
\mathrm{V}=\frac{\sum \mathrm{s}}{[\mathrm{n}(\mathrm{C}-1)]}
$$

$\mathrm{S}=\mathrm{r}-\mathrm{lo}$

lo $=$ lowest rating score (e.g. 1)

$\mathrm{C}=$ highest rating score (e.g. 5)

Table 1. Aiken's validation criteria

$r=$ number given by the evaluator

$\mathrm{n}=$ number of evaluators

\begin{tabular}{|c|c|c|}
\hline No & Index & Category \\
\hline 1 & $0.81-1.0$ & Very Good \\
\hline 2 & $0.41-0.8$ & Good \\
\hline 3 & $<0.4$ & Very Poor \\
\hline
\end{tabular}


Development of Education for Sustainable

Development (ESD) based Chemsdro Mobile Learning for Indonesian Junior High School: Rate Of Reaction

Table 1 showed that the developed learning media had a coefficient ( $\mathrm{V}$ ) Aiken's $\mathrm{V}$ value of 0.9 which means that learning media was categorized as very feasible to be used.

First step of this research was identifying the basic problems in SMA 1 Kendal. The initial activities were carried out at this stage: (1) observation, (2) interviews of chemistry teachers and vice-principals, (3) questionnaire needs of students, (4) documentation. Based on the results of student questionnaire needs, observation and teacher interviews, it showed that students tended to have an audio-visual learning style type and a low level of concern for students about environmental sustainability.

The second stage was the Design stage. The results of the analysis at this stage was used as a reference for Chemsdro learning media products based on education for sustainable development (ESD). The design of the media is adjusted to the learning characteristics of the students.

The next stage is the Develop stage which is divided into two stages, namely Expert appraisal and Developmental testing. Expert appraisal was conducted to determine the feasibility of the developed media. Expert judgment was carried out by experts namely lecturers and chemistry teachers. Material experts assessed products that had been developed in terms of material content. While media experts judged in terms of the appearance and design of the developed media. The suggestions given by the validator can be seen in Table 2.
Table 2. Experts Suggestions

\begin{tabular}{|l|l|}
\hline \multicolumn{1}{|c|}{$\begin{array}{c}\text { The } \\
\text { Experts }\end{array}$} & \multicolumn{1}{|c|}{ Suggestions } \\
\hline Experts-1 & $\begin{array}{l}\text { Added learning objectives, } \\
\text { chapter collision theory could be } \\
\text { more specifics and learning } \\
\text { questions must be higher order } \\
\text { thinking skills }\end{array}$ \\
\hline Validator 2 & $\begin{array}{l}\text { Chemsdro's media would be } \\
\text { better if it was developed for } \\
\text { another chemistry chapter. }\end{array}$ \\
\hline Validator 3 & $\begin{array}{l}\text { Background colors in the core } \\
\text { competency section were made } \\
\text { more contrasted. }\end{array}$ \\
\hline
\end{tabular}

The developmental testing phase is the design testing activity of the product that was developed on the actual target subject. Developmental testing phase only reached the initial testing stage, namely the product design is tested in the field with a limited number of users. The subject of this study was conducted in class XI MIPA 6 SMA N 1 Kendal. This design trial aimed to find out students' responses to the quality of developed learning media.

\section{RESULT AND DISCUSSION}

Technological development cannot be denied in this life, because it will grow according to scientific development. Every innovation was created to provide positive benefits for human life, and many conveniences as a new way of doing human activities. Although the originally creation of technology is intended to be able to produce positive benefits for human life. However there is a threat that probably can harm and endanger humanity when it is misused.

Another factor that underlies to develop Chemsdro's learning media is the concern of technology usage that is not used positively especially among students. The results of the questionnaire showed that $100 \%$ of students 
Development of Education for Sustainable

Development (ESD) based Chemsdro Mobile Learning for Indonesian Junior High School: Rate Of Reaction

who have an android, only $13 \%$ of students use android for learn. It gave a strong reason to utilize technology to be able to be used positively by students, especially in learning chemistry. Chemistry learning should have innovation and be able to meet the demands of the 21st century by providing a bridge between chemistry content and students' real lives, thus raising awareness of a better world sustainability (Fibonacci, 2012). Chemdro learning media is designed by incorporating elements of education for sustainable development (ESD) and can be played on android mobile phones.

The development of science and technology can no longer be avoided in education, demands the education to always adjust the development of technology in an effort to improve the quality of education (Rusdi \& Yunus, 2014). One technology that supports the needs of students in an effort to improve the quality of education is an android smartphone (Muyaroah \& Farojtika, 2017).

Chemistry is considered as a difficult subject by students because chemistry consists of 3 levels namely macroscopic, microscopic and symbolic language when they want to connect these 3 things they need some help from the teacher and the surrounding environment which impact on students' perceptions of chemistry subjects (Ardac \& Akaygun, 2004).

The reaction rate is one topic in chemistry that is difficult based on student's perspective. The reaction rate had the highest percentage of chemicals difficult chapter that is equal to $40 \%$. This is commensurate to Nazar et al. (2010) which states that the reaction rate material is part of an abstract chemical concept, which often makes students found difficulties to understand the concept of reaction rate so

that needs help from media such as multimedia.

The pre-research results showed that most students stated that the media used in chemistry learning were books (visual) whereas most students had an audio-visual learning style so that the media needed was audio-visual learning media.

The results of the questionnaire responses of students on aspects of interest in the learning media showed a very good category which means that students' learning motivation increased by using Android-based learning media. This is based on the research of Pramuditya et al. (2017) which states that the game can be a learning medium to improve the development of a person's brain in motor power, cognitive, spiritual, so that the intellectual ability of the learner's brain.

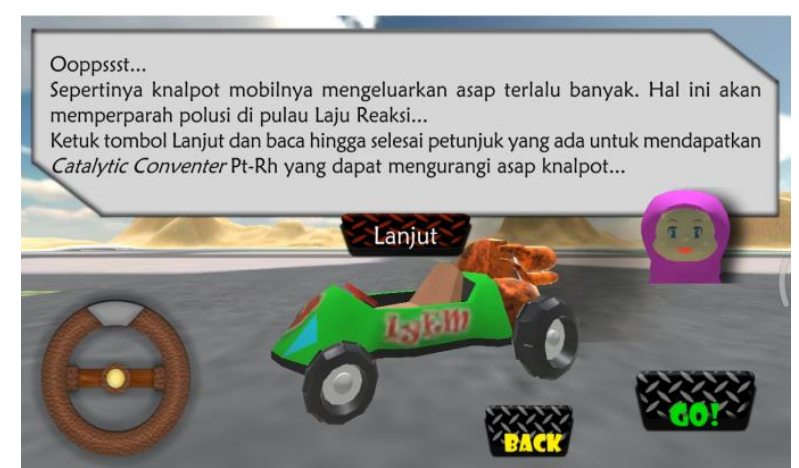

Figure 2. Exercise Menu in Chemsdro

Android-based chemistry learning media which was developed in this research is packaged in the form of games. The results of the pre-research showed that $100 \%$ of students need the content in the learning media is integrated with a game. Barab et al. (2010) stated that the integration of learning media with games enables a teacher to convey learning that will attract students' interest and to entertain students and it was expected to

Jurnal Tadris Kimiya 5, 1 (Juni 2020): 26-34

This is an open access article under CC-BY-SA license (https://creativecommons.org/licenses/by-sa/4.0/) 
Development of Education for Sustainable

Development (ESD) based Chemsdro Mobile Learning for Indonesian Junior High School: Rate Of Reaction

be able to dispel the notion that chemistry is difficult and boring. This is supported by the assessment of material experts and media that the developed learning media had a coefficient ( $\mathrm{V}$ ) Aiken's $\mathrm{V}$ value of 0.9 which means that learning media was categorized as very feasible to be used. This was confirmed by the results of the students' responses which showed that majority of students felt happy to learn chemistry by playing games. This was correlated with the results of the questionnaire responses of students which showed that the learning media was categorized well. The low caring attitude of students towards environmental sustainability based on the results of the environmental awareness questionnaire showed that $93.3 \%$ of students did not clean up trash before learning, $86.7 \%$ of students did not dispose of scattered rubbish, $60 \%$ of students did not participate in reboisation at school. The results of student questionnaire responses on ESD aspect showed a very good category which means that the Developed learning media can increase students' motivation towards caring attitudes to the environment.

The developed learning media was named Chemsdro it stands for Chemistry for Android. Chemsdro learning media was developed using Unity software which was made in the apk format (android package). Chemsdro learning media was already available in the play store and can be downloaded freely.

\section{CONCLUSION}

Based on the data and discussion, it can be concluded that the Chemsdro learning media has Special characteristics one of them is it is designed to motivate students towards environmental sustainability through education for sustainable development. Chemsdro is an adventure game. In this game, players were asked to complete environmental rescue missions using the concepts of reaction rates. Players will get additional features such as a catalytic converter, advanced steering wheel, which can be used to help overcome enemies who come in completing missions. The way players get these additional features is by answering challenges in the form of questions about the concept of reaction rate. Material and questions were packaged in the form of games oriented to education for sustainable development (ESD) in the form of illustrations to solve environmental problems through games answering questions in a polluted island where students are required to solve problems in polluted islands by growing trees through practice exercises. If the problem is answered correctly, the tree will grow up and pollution will decrease, and if the answer is wrong, the tree will shrink and pollution will be thicker. Chemsdro learning media based on Android oriented education for sustainable development (ESD) was declared very feasible by the validator based on the Aiken's $V$ coefficient of 0.9. Furthermore the results of the questionnaire responses of students that the Chemsdro learning media oriented education for sustainable development (ESD) showed a good category. 
Development of Education for Sustainable Development (ESD) based Chemsdro Mobile Learning for Indonesian Junior High School: Rate Of Reaction

\section{REFERENCES}

Abanikannda, M. O. (2016). Prospects of learning chemistry through mobile digital devices. Int. J. Educ. Learn. Dev., 4(4), 29 36.

Ahiakwo, M. J., \& Isiguzo, C. Q. (2015). Students' conceptions and misconceptions in chemical kinetics in port harcourt metropolis of Nigeria. African Journal of Chemical Education, 5(2), 112-130.

Ardac, D., \& Akaygun, S. (2004). Effectiveness of multimedia-based instruction that emphasizes molecular representations on students' understanding of chemical change. Journal of research in science teaching, 41(4), 317-337.

Arslan, H. O., Moseley, C., \& Cigdemoglu, C. (2011). Taking attention on environmental issues by an attractive educational game: Enviropoly. Procedia-Social and Behavioral Sciences, 28, 801-806.

Azwar, S. (2012). Reliabilitas dan validitas edisi 4. Yogyakarta: Pustaka Pelajar.

Barab, S. A., Sadler, T. D., Heiselt, C., Hickey, D., \& Zuiker, S. (2010). Erratum to: Relating Narrative, Inquiry, and Inscriptions: Supporting Consequential Play. Journal of Science Education and Technology, 19(4), 387-407.

Cachapuz, A. F. C., \& Maskill, R. (1987). Detecting changes with learning in the organization of knowledge: Use of word association tests to follow the learning of collision theory. International Journal of Science Education, 9(4), 491-504.

Díaz, M. D., Gómez, C. H., \& De-la-calle, A. M. (2019). Professional Action Competences

Through Experiences With Augmented Reality. Journal of Turkish Science Education, 16(4), 554-568.

El-Sofany, H. F., El-Seoud, S. A., Alwadani, H. M., \& Alwadani, A. E. (2014). Development of Mobile Educational Services Application to Improve Educational Outcomes using Android Technology. International Journal of Interactive Mobile Technologies (IJIM), $8(2), 4$.

Engjellushe, E. (2013). Education for sustainable development. European Journal of Sustainable Development, 2(4), 227-227.

Fibonacci, A. (2012). Peningkatan Hasil Belajar IPA Siswa Kelas X TKR1 SMK N 7 Semarang melalui Joyful Learning Menggunakan Game Guess My Word. Jurnal Penelitian Pendidikan, 29(2), 93100.

Henich, R., Molenda, M., Russell, J. D., \& Smaldino, S. E. (1999). Instructional Media and Technology for Learning.

Jauhari, J. (2009). Studi Terhadap Penggunaan Multimedia Interaktif Dalam. Prosiding Seminar Nasional Penelitian, Pendidikan Dan Penerapan MIPA, 425-432.

Laurie, R., Nonoyama-Tarumi, Y., Mckeown, R., \& Hopkins, C. (2016). Contributions of education for sustainable development (ESD) to quality education: A synthesis of research. Journal of Education for Sustainable development, 10(2), 226-242.

Muyaroah, S., \& Fajartia, M. (2017). Pengembangan Media Pembelajaran Berbasis Android dengan menggunakan Aplikasi Adobe Flash CS 6 pada Mata Pelajaran Biologi. Innovative Journal of

\footnotetext{
This is an open access article under CC-BY-SA license (https://creativecommons.org/licenses/by-sa/4.0/)
} 
Development of Education for Sustainable Development (ESD) based Chemsdro Mobile Learning for Indonesian Junior High School: Rate Of Reaction

Curriculum and Educational Technology, 6(2), 79-83.

Nazar, M., Sulastri, S., Winarni, S., \& Fitriana, R. (2010). Identifikasi miskonsepsi siswa SMA pada konsep faktor-faktor yang mempengaruhi laju reaksi. Jurnal Biologi Edukasi, 2(3), 49-53.

Nugroho, R. S., \& Purwandari, N. (2016). Implementasi Blended Learning Multimedia Berbasis Smartphone Untuk Pengayaan Pembelajaran Pada Sekolah XYZ. Jurnal Sains Dan Teknologi, 3(1), 3748.

Perkasa, M., Agrippina, A., \& Wiraningtyas, W. (2017). Sustainable Chemistry Oriented on Chemistry Learning to Increase Student Awareness to the Environment. Sainsmat: Jurnal Ilmiah Ilmu Pengetahuan Alam, 6(2), 169-178.

Pramuditya, S. A., Noto, M. S., \& Syaefullah, D. (2017). Game Edukasi Rpg Matematika. Eduma: Mathematics Education Learning and Teaching, 6(1), 77-84.

Rohmah, L. (2014). Implementasi Kurikulum Berbasis Education for Sustainable Development (ESD) di SDIT Internasional Luqman Hakim Yogyakarta. Al-Bidayah: Jurnal Pendidikan Dasar Islam, 6(2).

Rusdi, H., \& Yunus, M. (2014). Pengembangan Media Pembelajaran Berbasis Android "ChemBird" Pada Materi Kimia Kelas XI di SMAN 17 Makassar. Jurnal Ecosystem, 16.

Segara, N. B. (2015). Education for Sustainable Development (ESD) Sebuah Upaya Mewujudkan Kelestarian Lingkungan. Sosio Didaktika: Social Science Education Journal, 2(1), 22-30.

Sidabutar, E. D. C., Faniudin, M. N., \& Said, M. (2013). Pengaruh Rasio Reaktan Dan 